\title{
Notes on the vocalizations of Common Bush-tanager (Chlorospingus ophthalmicus)
}

Peter Boesman

In the following we briefly analyze and compare voice of the different races of Common Bush-tanager (Chlorospingus ophthalmicus). We also try to quantify the extent of any vocal differences using the criteria proposed by Tobias et al. (2010), as a support for taxonomic review. We have made use of sound recordings available on-line from Xeno Canto (XC) and Macaulay Library (ML).

With 26 subspecies this is clearly a very complex case.

An overview of vocalizations illustrated with sonograms:

1. Northern group (characterized by lacking a specific dawn song)

Chlorospingus (ophthalmicus) ophthalmicus (Brown-headed Bush-tanager) Long call or song
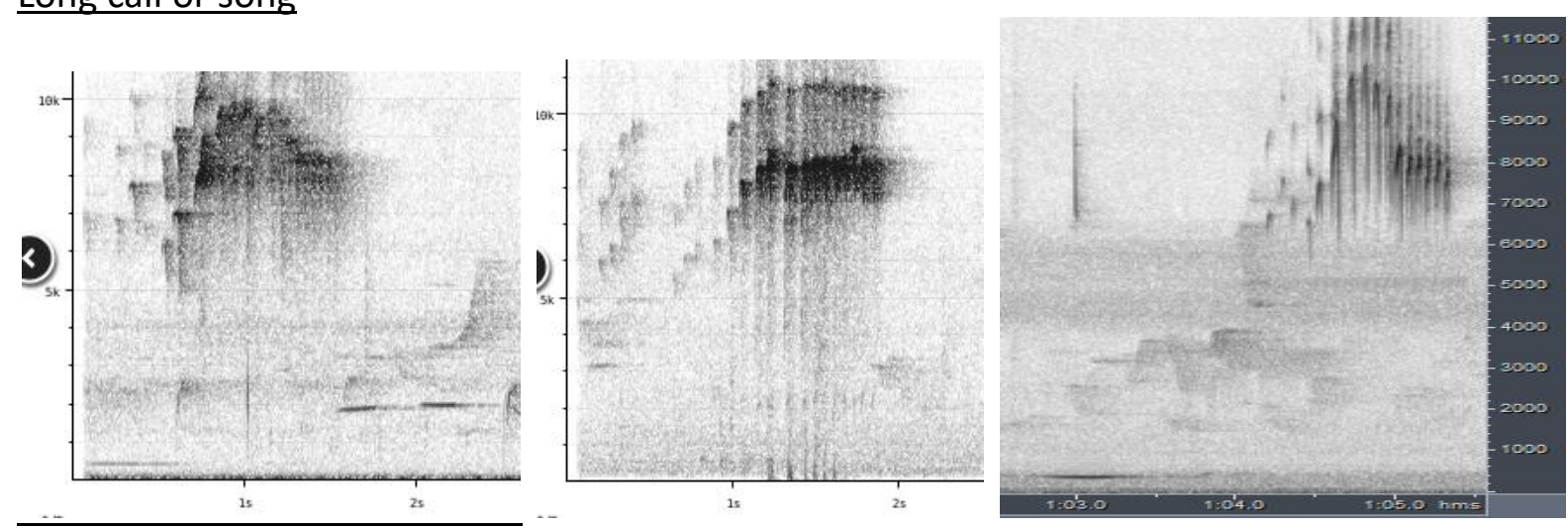

Chlorospingus (ophthalmicus) postocularis (Dusky-headed Bush-tanager) Long call or song
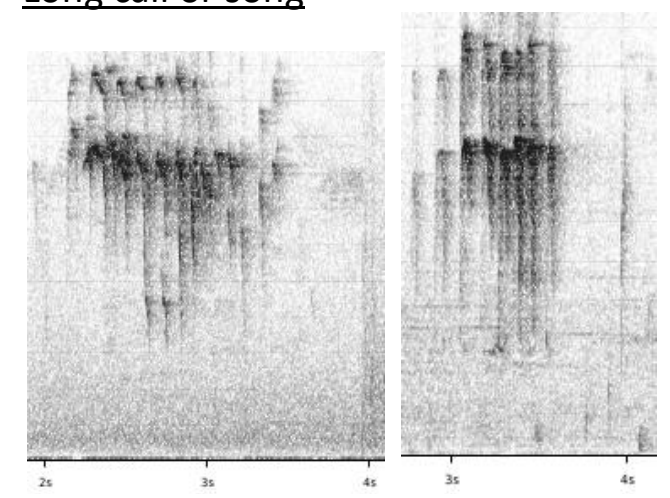


\section{HANDBOOK OF THE \\ BIRDSPFGE WORLD}

\section{ORNITHOLOGICAL NOTES}

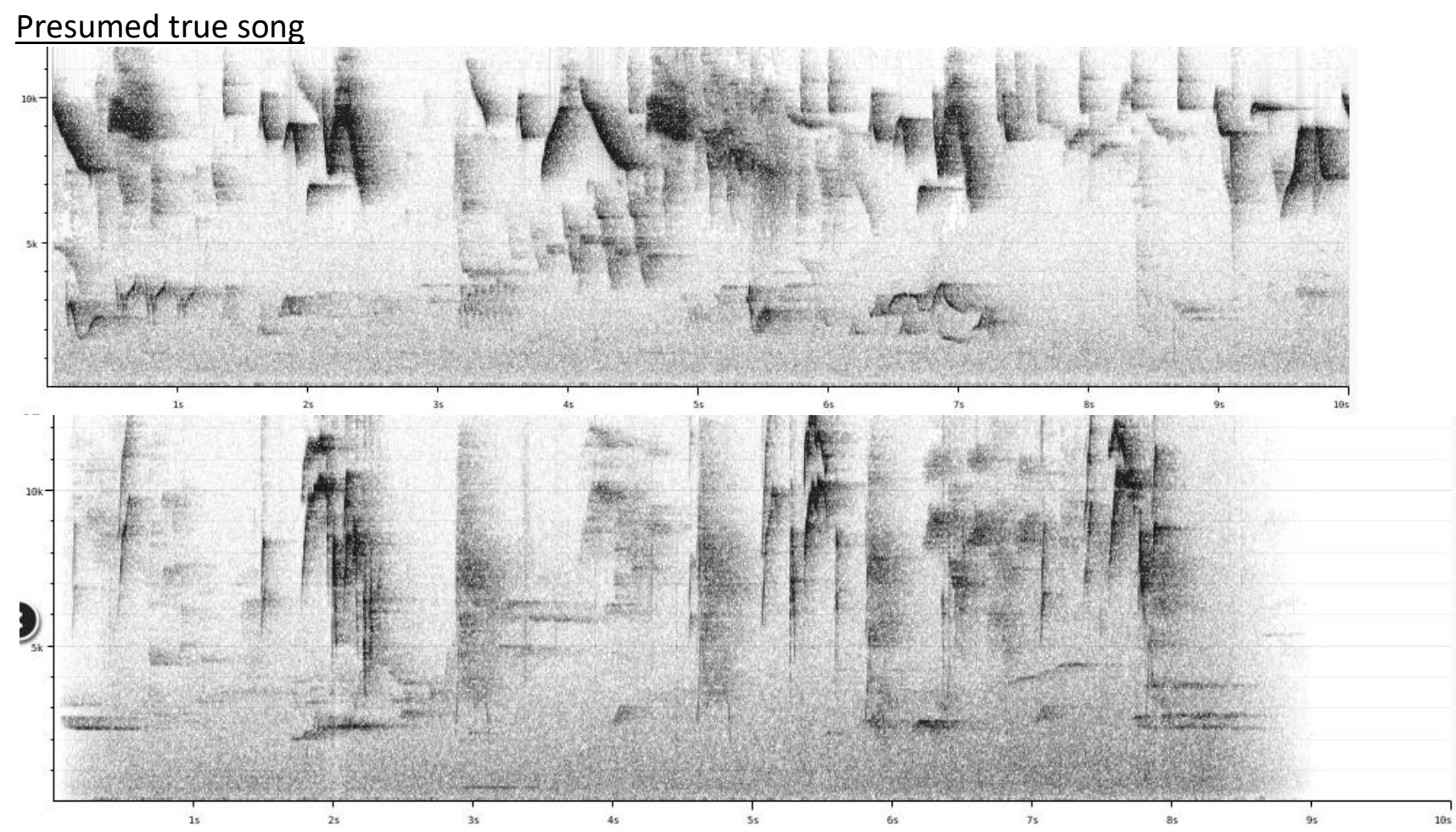

Chlorospingus (ophthalmicus) albifrons (White-fronted Bush-tanager)

No recordings available

Chlorospingus (ophthalmicus) dwighti (Dwight's Bush-tanager)

Long call or song

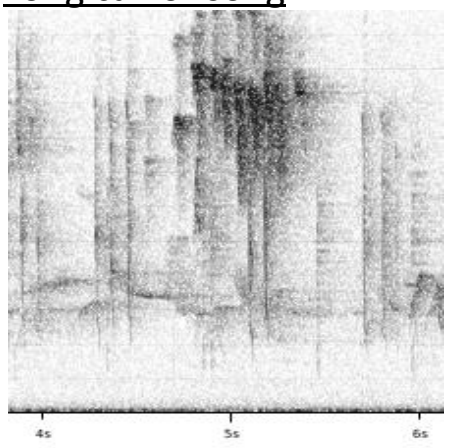

Presumed true song

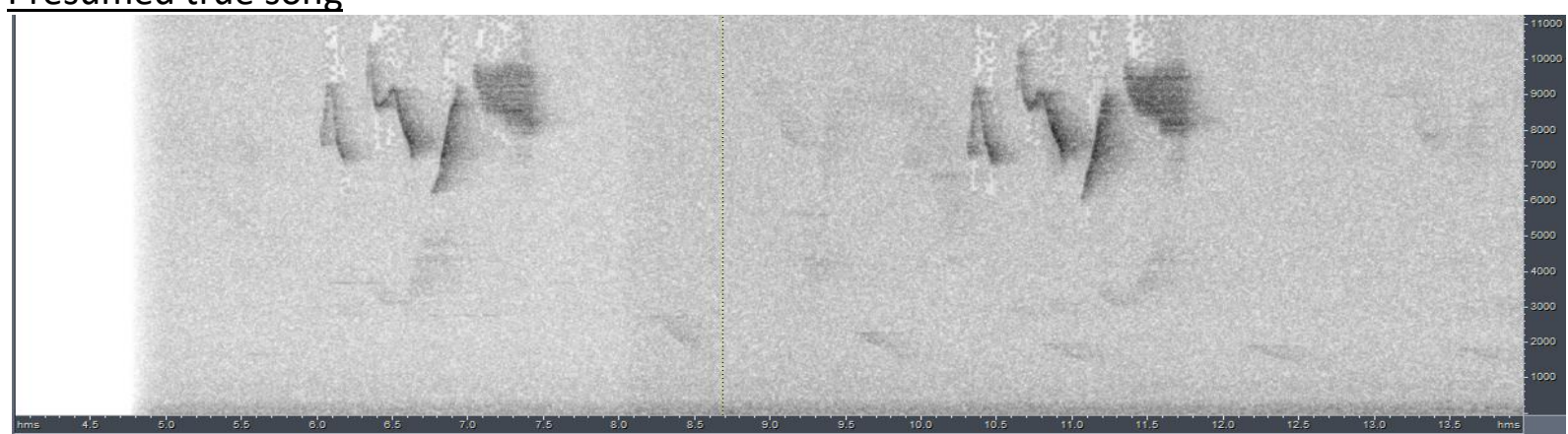



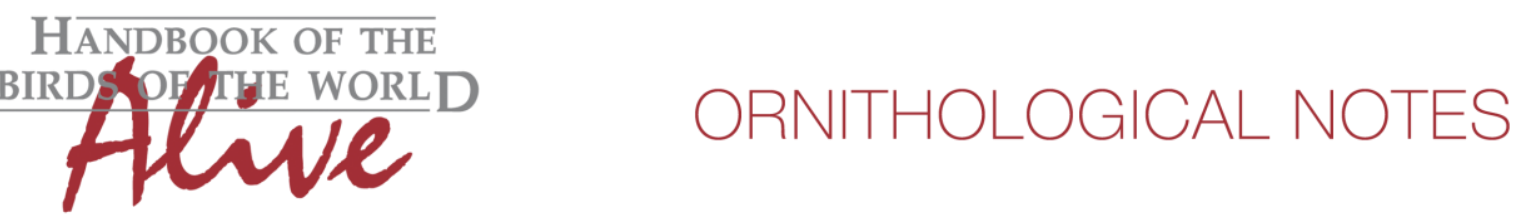

Chlorospingus (ophthalmicus) wetmorei (Wetmore's Bush-tanager)

Long call or song

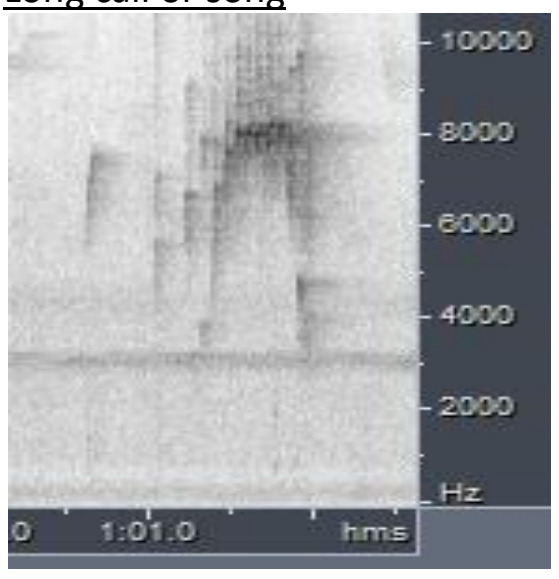

Chlorospingus ophthalmicus regionalis (Dotted Bush-tanager)

\section{Long call or song}
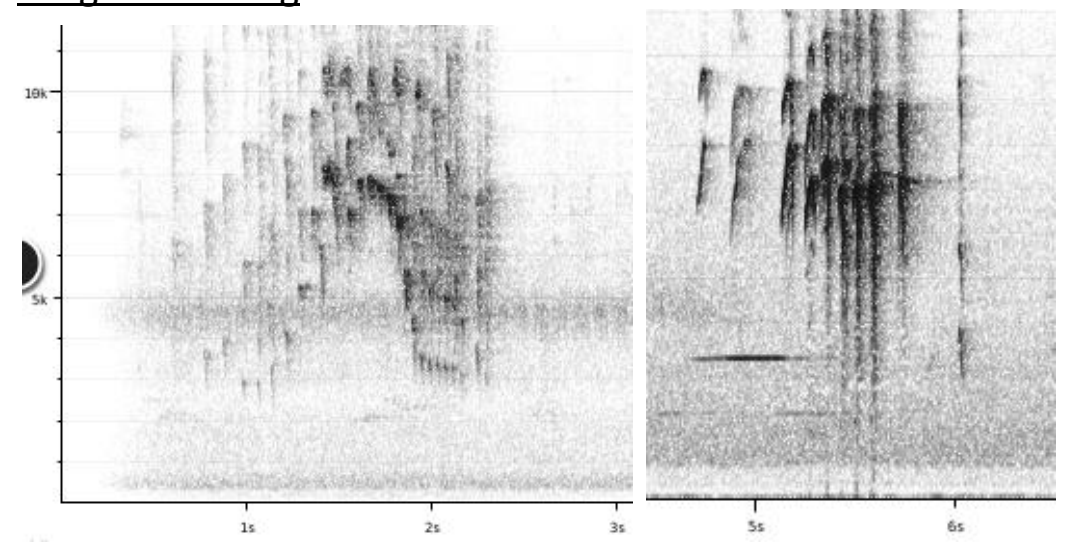

\section{Presumed true song}

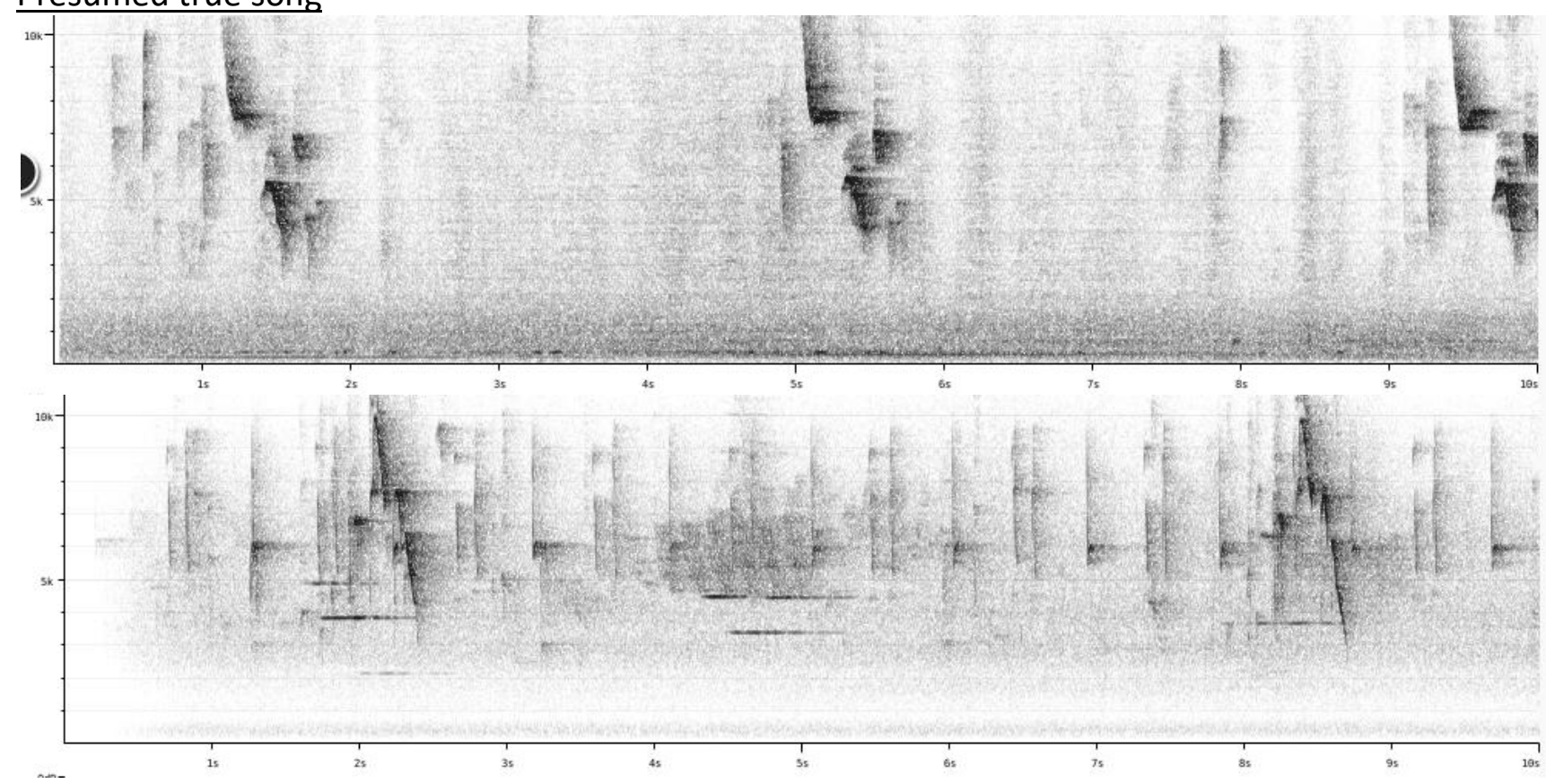


2. Southern group (characterized by a stereotypic dawn song)

Chlorospingus (opthalmicus) venezuelensis (with jacqueti and ponsi) ('Common Bushtanager')

Dawn song

Venezuela

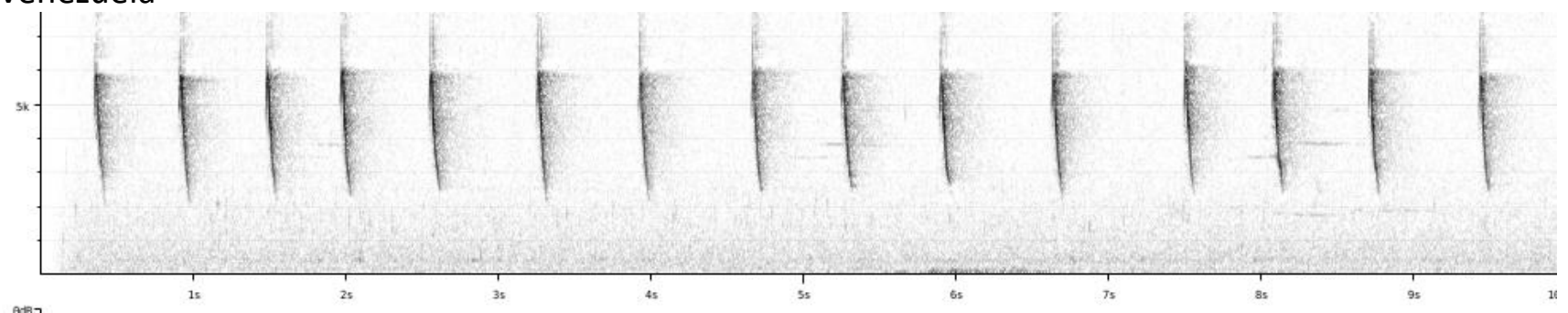

Perija (ponsi)

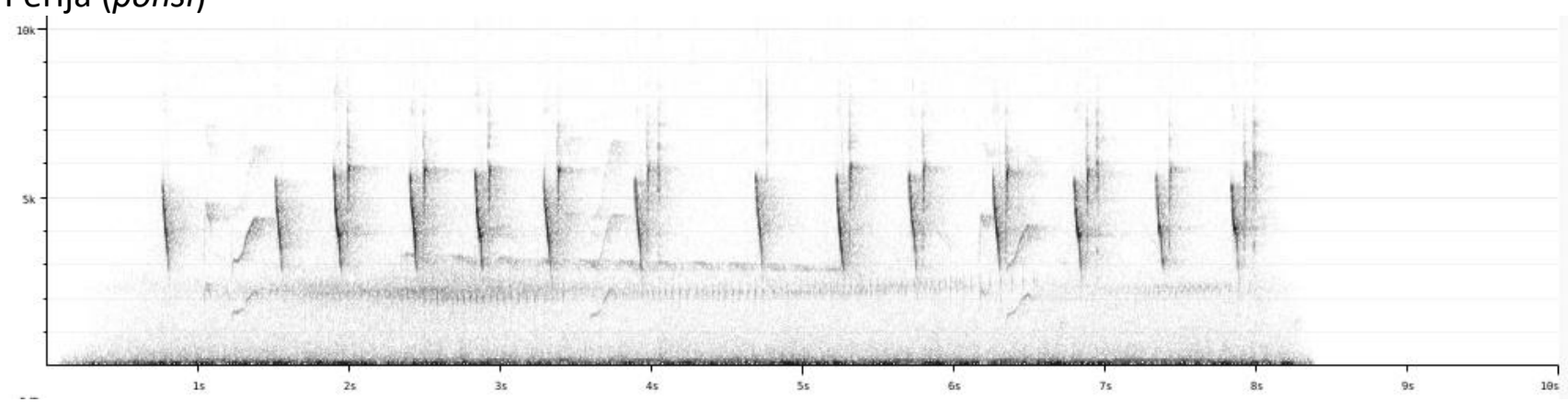

Long call

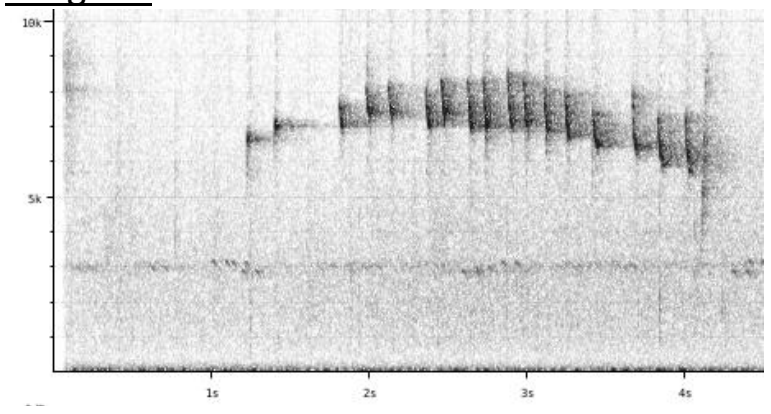

C. o. eminens, $C$. o. exitelus and C. o. trudis

Dawn song

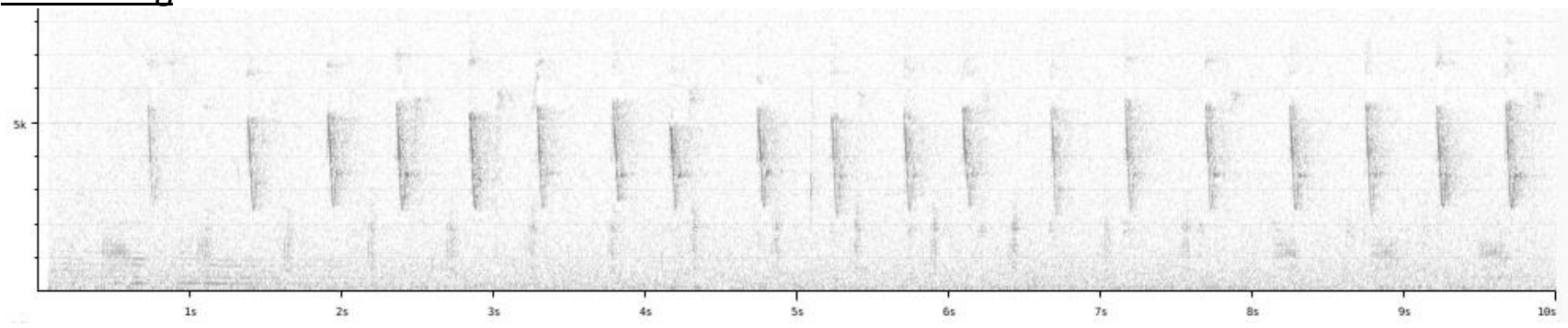


HANDBOOK OF THE

BIRDS PF TUE WORLD

ORNITHOLOGICAL NOTES

Howe

Coo. flavopectus

Dawn song is distinctly low-pitched:
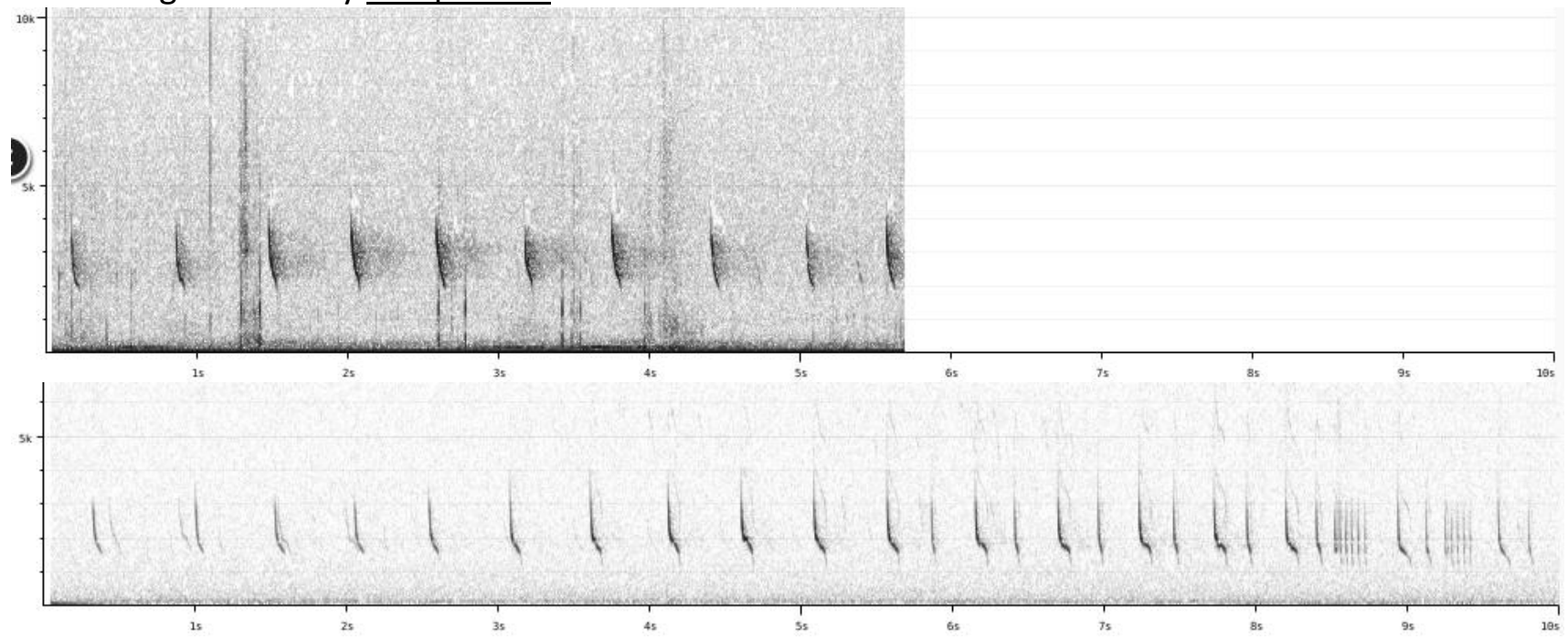

Coo. phaeocephalus

Dawn song is distinctly high-pitched:

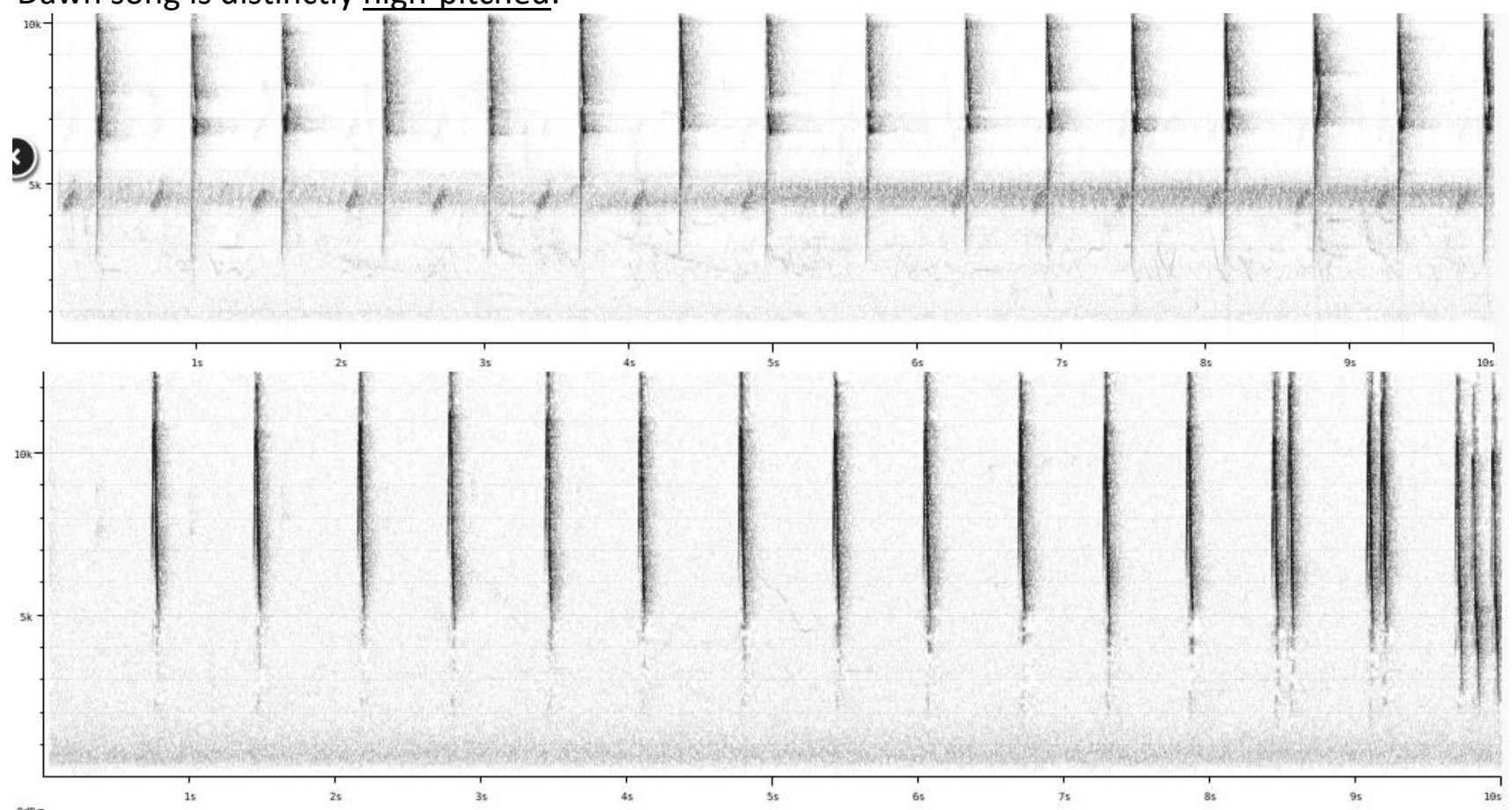

5 


\section{C.o.hiaticolus}

Dawn song is medium to high-pitched and rhythmic at the end:
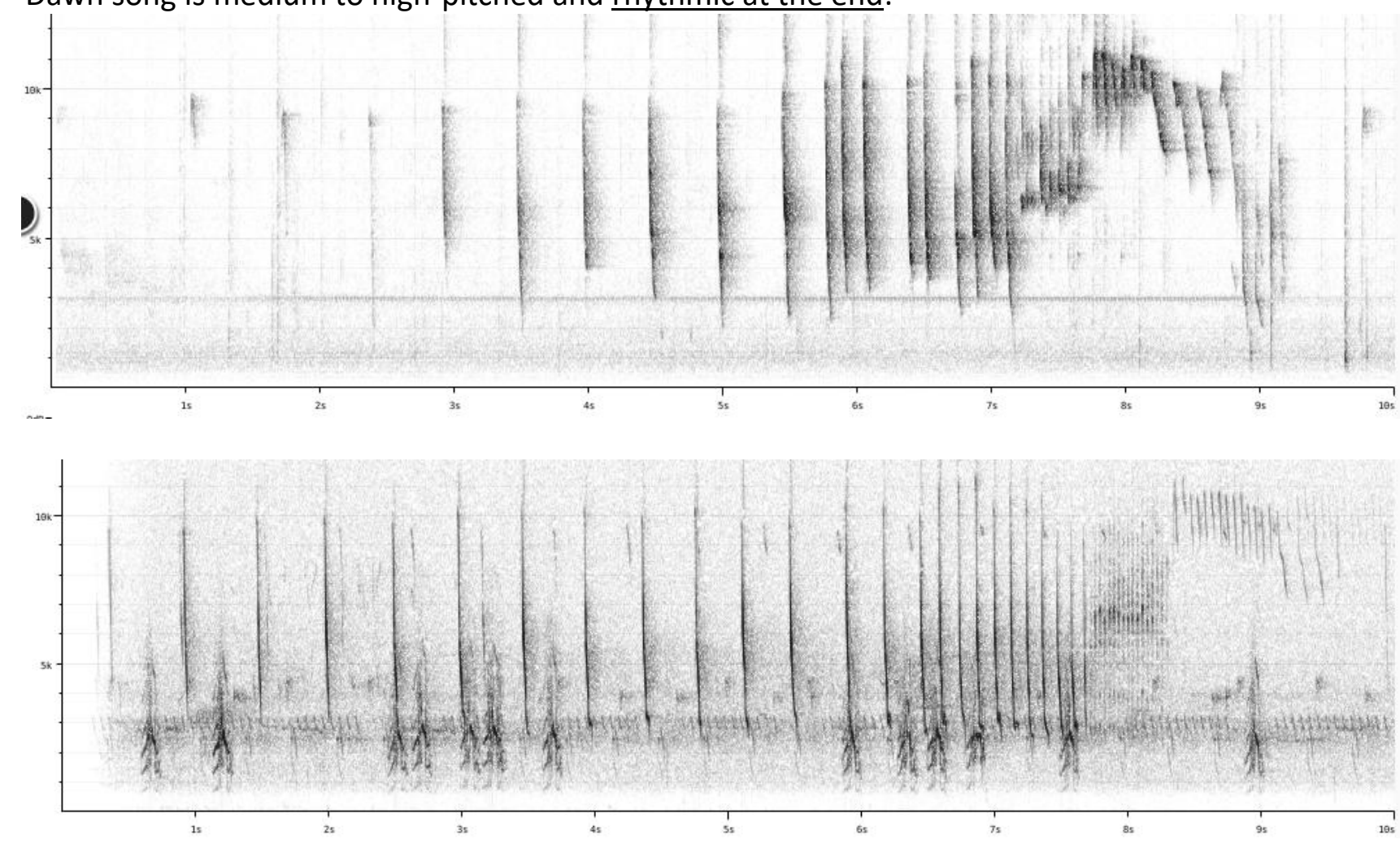

\section{C.o.cinereocephalus}

Dawn song is low pitched

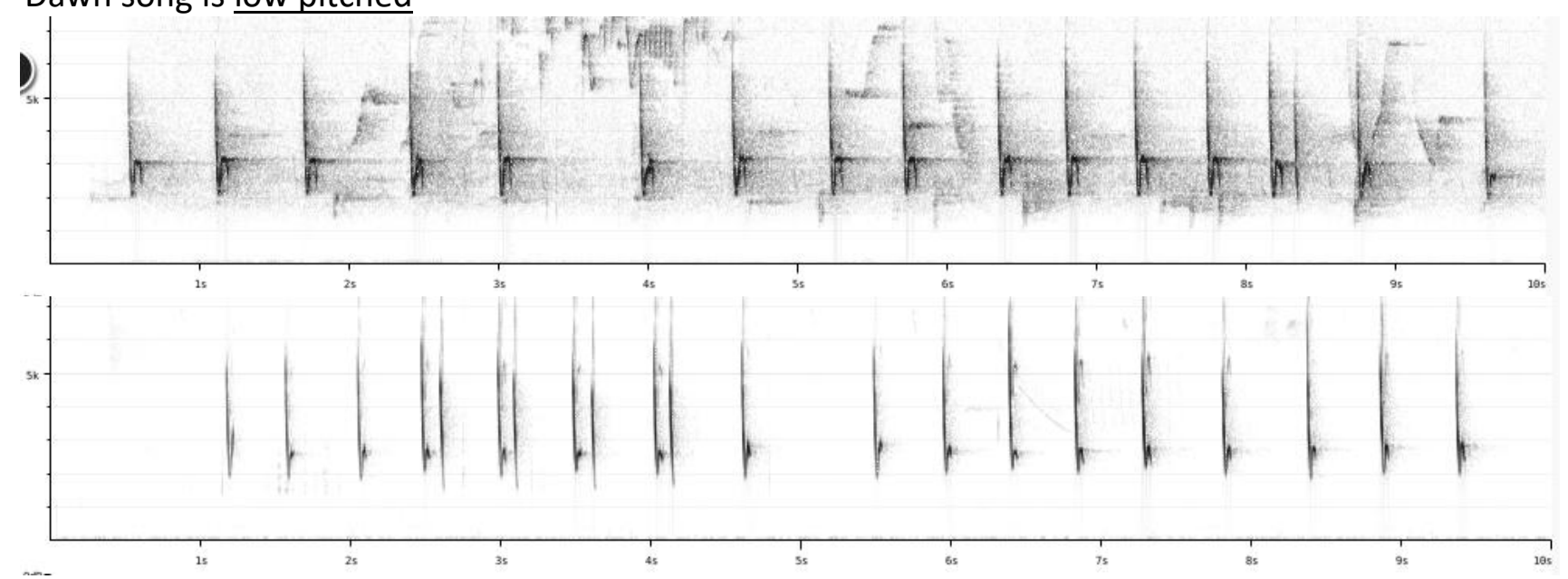




\section{HANDBOOK OF THE \\ Alve}

\section{C.o. bolivianus and fulvigularis (Bolivia)}

Dawn song more like $\mathrm{N}$ Andean birds
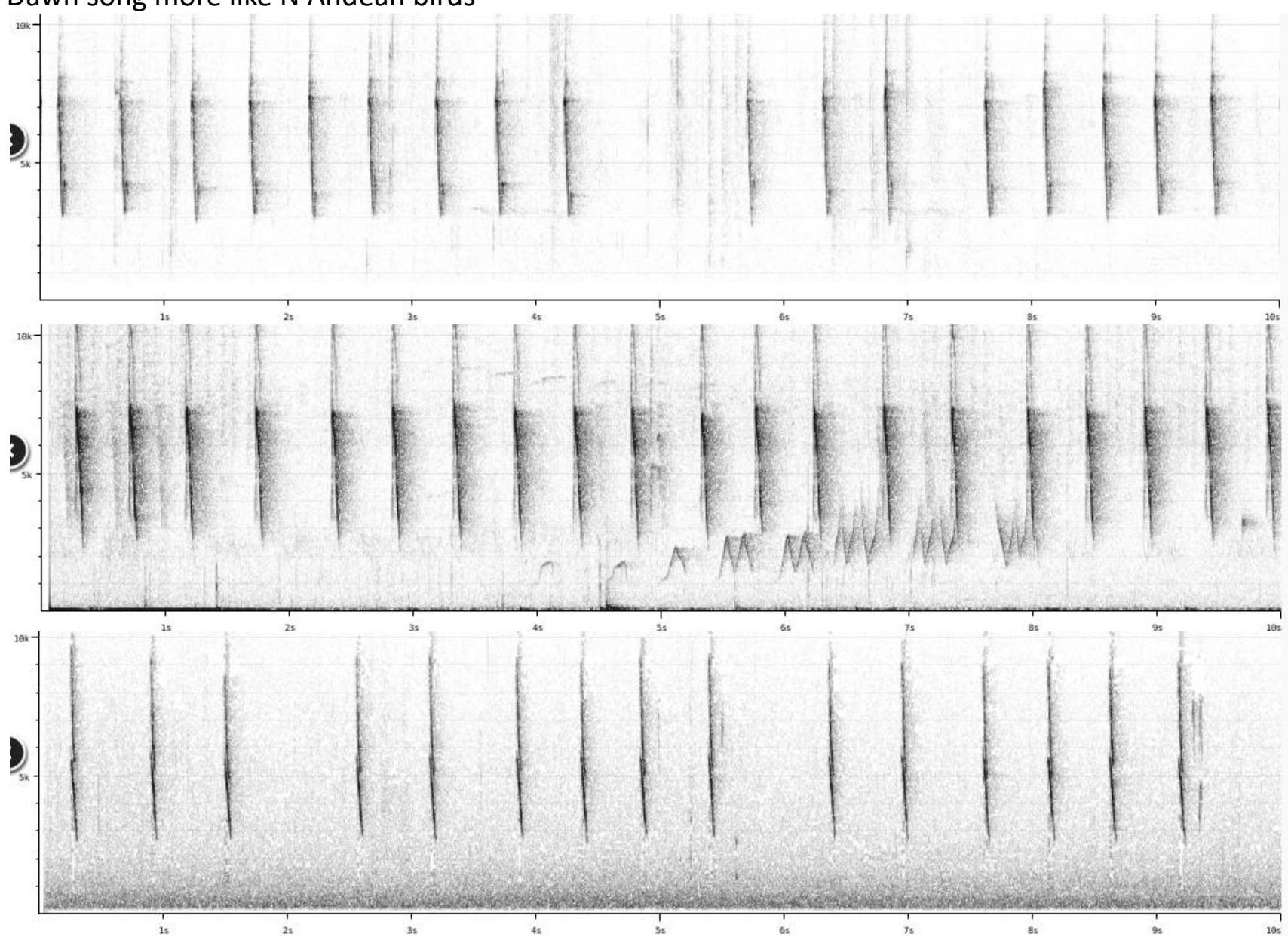

\section{C. o. argentatus}

Dawn song more like N Andean birds

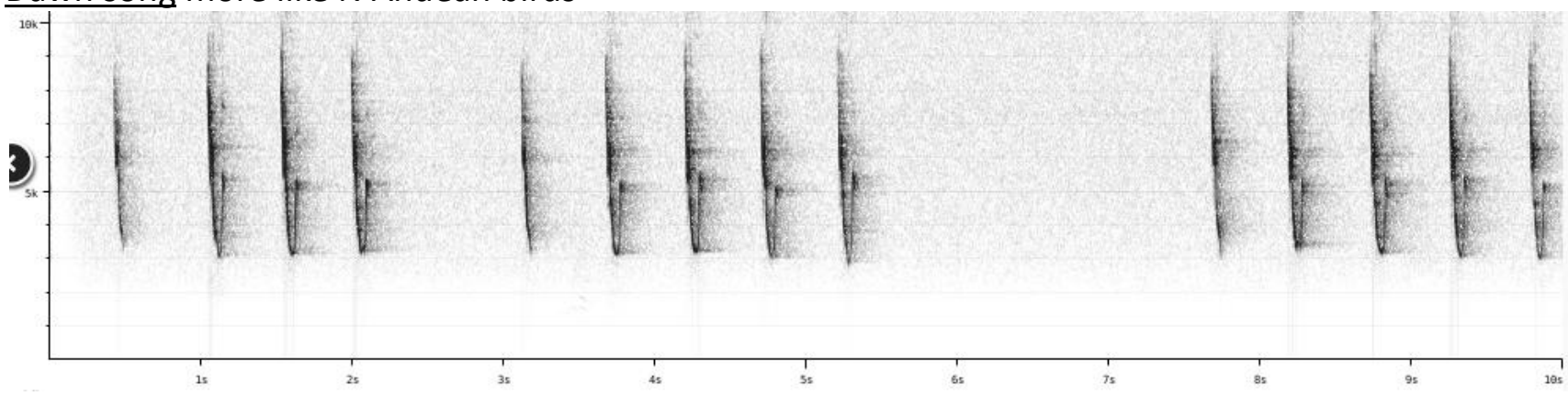



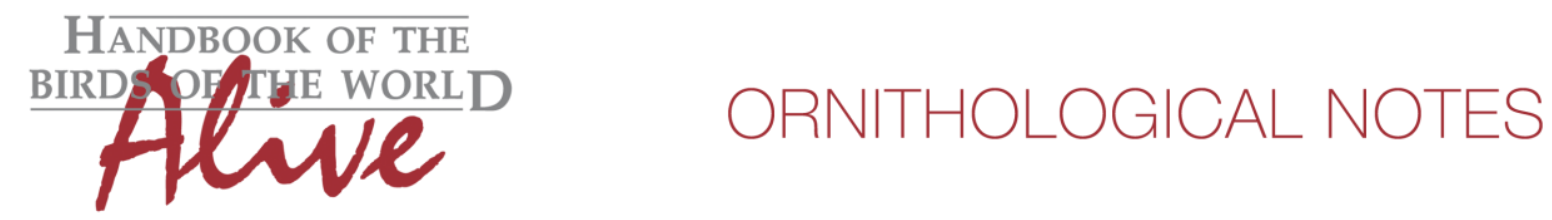

It is clear that this brief overview does not allow to unravel the complex issues of this case. Nevertheless, the following can be concluded:

* There is an important difference between Mexican/Central-American taxa (Northern group) and South-American taxa (Southern group): the latter have a characteristic monotonous dawn-song (not unlike a Sparkling Violetear Colibri coruscans), the former seem to utter at dawn only the high-pitched chatters which can also be heard during day-time (score 4). If a split would be considered, this would seem vocally the most important dividing line.

* In the Northern group, there is for some races confusion about what exactly is the song (further complicated by a few misidentifications, e.g ML146004 being Spot-crowned Woodcreeper Lepidocolaptes affinis affinis). It would require an in depth analysis of all vocalizations to find out about further vocal differences, such as e.g. done in Sosa-Lopez et al. (2013). Their conclusion basically is that albifrons and regionalis are vocally most distinct. (These are however also the 2 races for which the authors have used recordings from only one locality). The distinctiveness of regionalis from the Costa-Rican/Panamanian highlands would not be surprising, as it is quite disjunct from populations both towards the north and the south and given this region is such an important endemic center. This clearly needs further study.

* In the Southern group, comparison of dawn songs learns that there is considerable difference among races:

- flavopectus and cinereocephalus have a distinct low-pitched dawn song - phaeocephalus has a distinct high-pitched dawn song (somewhat similar to Dusky Bushtanager C. semifiscus)

- hiaticolus has a distinct dawn song with rhythmic accelerations and pitch changes towards the end

- Other races differ less, with only note shapes different, but would require further study.

This note was finalized on 24th May 2016, using sound recordings available on-line at that moment. We would like to thank in particular the many sound recordists who placed their recordings for this species on $\mathrm{XC}$ and $\mathrm{ML}$.

\section{References}

Sosa-López, J.R., González, C. \& Navarro-Sigüenza, A.G. (2013). Vocal geographic variation in Mesoamerican Common Bush Tanagers (Chlorospingus ophthalmicus). Wilson J. Orn. 125(1): 24-33.

Tobias, J.A., Seddon, N., Spottiswoode, C.N., Pilgrim, J.D., Fishpool, L.D.C. \& Collar, N.J. (2010). Quantitative criteria for species delimitation. Ibis 152(4): 724-746. 


\section{Recommended citation}

Boesman, P. (2016). Notes on the vocalizations of Common Bush-tanager (Chlorospingus ophthalmicus). HBW Alive Ornithological Note 359. In: Handbook of the Birds of the World Alive. Lynx Edicions, Barcelona. (retrieved from http://www.hbw.com/node/1252902 on 28 October 2016). 